\title{
The Influence of CSR Practices on Financial Performance: Evidence From Islamic Financial Institutions in Indonesia
}

\author{
Firman Menne \\ Bosowa University, Makassar, Indonesia \\ Lanita Winata, Mohammad Hossain \\ Griffith University, Queensland, Australia
}

\begin{abstract}
The emergence of Islamic Financial Institutions (IFIs) is expected to provide enormous benefits for the Muslims community in Indonesia such as the availability of IFIs based on Sharia law and the implementation of Islamic value in the community. Like Corporate Social Responsibility (CSR) practices in all business organizations, the IFI's CSR becomes one of the important factors in improving organizational performance. The implementation of CSR in IFIs is unique as it is based on Sharia law. Zakat and Qardh are the uniqueness of IFI's CSR practices. There are many studies which have investigated the relationship of Zakat and Qardh on organizational performance in Arabic and Muslim countries. As Muslim countries, Islamic laws including providing Zakat and Qardh are practices of every business organization. Indonesia is not a Muslim country, Zakat and Qardh are only required for IFIs as part of CSR practices. This study aims to analyze the influence of CSR practices on the financial performances of IFIs in Indonesia using gender as a control variable. The samples of this research were taken from the annual reports of nine Islamic banks for the period of 2010-2014. Regression method was used to analyze and test hypotheses. The results of this research indicate that the relationship between CSR practices and financial performance is significant, the value of $R$ is 0.737 , and $R$ square is 0.543 . This means that the implementation of CSR practices (Zakat and Qardh) improves organizational financial performances of IFIs in Indonesia. This study also has a limitation as it only focuses on Zakat and Qardh; thus in the future, it is necessary to advance the variable of CSR practices on the real social and environmental practices such as environmental improvement, increasing the quality of human resources, involving in any jobs or reducing unemployment and any other activities.
\end{abstract}

Keywords: CSR practices, financial performances, gender, Islamic financial institutions (IFIs)

\section{Introduction}

The development of Islamic Financial Institutions (IFIs) in Indonesia has shown a fairly positive trend as shown in Table 1, This is an important development achieved by Indonesia as a country that is known with a Muslim majority population even as the country with the largest Muslim population in the world. Furthermore, the effort to build the strong IFIs in Indonesia could not be released from the implementation of Corporate Social Responsibility (CSR) practices in any IFIs.

Firman Menne, CA, lecturer, Department of Accounting, Bosowa University. Email: firman@univ45.ac.id. Lanita Winata, Ph.D., lecturer, Department of Accounting, Finance and Economics, Griffith University. Mohammad Hossain, Ph.D., lecturer, Department of Accounting, Finance and Economics, Griffith University. 
Table 1

The Development of IFIs in Indonesia

\begin{tabular}{lrrrrrr}
\hline The number of & 2009 & 2010 & 2011 & 2012 & 2013 & 2014 \\
\hline ICU & 6 & 11 & 11 & 11 & 11 & 12 \\
Offices & 711 & 1,215 & 1,390 & 1,734 & 1,987 & 2,151 \\
SBU & 25 & 23 & 24 & 24 & 23 & 22 \\
Offices & 287 & 262 & 312 & 493 & 567 & 320 \\
SRB & 138 & 150 & 155 & 158 & 163 & 163 \\
Offices & 223 & 286 & 364 & 401 & 402 & 439 \\
Sharia Pawnshop & 287 & 157 & 135 & 152 & 156 & 156 \\
Sharia Insurance & 42 & 45 & 43 & 45 & 49 & 50 \\
Total number of offices & 1,550 & 1,965 & 2,244 & 2,825 & 3,161 & 3,116
\end{tabular}

Notes. Source: Otoritas Jasa Keuangan (OJK), Modified, 2015. ICU = Islamic Commercial Bank; SBU = Sharia Business Units; SRB = Sharia Rural Bank.

During the past five years, IFIs in Indonesia have shown their role in disclosing the CSR report as a complement of their annual reports, despite that there are not many studies focusing on the effect of CSR practices on financial performances of IFIs. Moreover, CSR practices in IFIs have uniqueness in their reports using Islamic Accounting Standards (IAS).

Indonesia has adopted IAS as noted in several statements in its Statement of Financial Accounting Standard (PSAK). In 2003, Islamic Accounting Standard Board authorized PSAK 59 about Islamic Banking, and subsequently in 2007, it authorized again PSAK 101-109 about Islamic Financial Statement, Murabahah, Salam, Istishna, Mudharabah, Musyarakah, Ijarah, Islamic Insurance, and Zakat. Implementation of this IAS surely will become a different thing compared with other cases in other countries especially in Western countries. Islamic Accounting as a standard for IFIs has become a guideline to manifest and involve themselves in their transactions, included there in the society, environment, and the universe. The last sentences refer to the CSR. It means that CSR practice in IFIs is an implementation of the content of Qur'an, for example, Allah says that, "And when it is said to them, 'Do not cause corruption on the earth', TQS 2:11" (Rahman, 2009, 2:11). This verse implies that the practice of CSR is God's command, not merely as a form of accountability to the society but also accountability to God.

However, is there a positive relationship between CSR practices and financial performances of IFIs? To answer this question, this research aims to analyze the influence of CSR practices on financial performances of IFIs in Indonesia using gender as a control variable.

\section{Literature Review of Previous Research}

\section{CSR: Concept and Measurement}

The concept of CSR has long been known in business field, as has been proposed by a number of previous researchers, such as Friedman (1970) who stated that for a long time ago, managers will not have money profit as their objective, but they are also ultimately thinking about social problems. In addition, Garriga and Mele (2004) said that since the second half of the 20th century, a long debate on CSR has been taken. Even over the past 50 years, business ethicists and management theorists have devoted much effort to studying and analyzing the business-society relationship. 
The notion of CSR is expressed in many other connotations in different organizations with other names such as Socially Responsible Corporation (SRC) or Corporate Responsibility (CR). All things refer to the terminology of corporate responsibility to stakeholder including the community and nature around the corporate. Siwar and Hossain (2009) said that CSR is an organization's commitment to conducting its business in an economically, socially, and environmentally sustainable manner whilst balancing the interests of a diverse range of stakeholders. CSR refers to business, ethically responsible to its stakeholders. The simple notion of CSR is mentioned by Zakaria and Gao (2011) that CSR refers to the relation of a corporation society as a whole.

To complete the notion of CSR, Carroll (1979) mentioned the typology of CSR as follows: (1) economic: fulfilling consumer needs, providing jobs and respectable wages, and raising capital for investment; (2) legal: complying with laws and regulations; (3) ethical: undertaking morally justifiable codes and conduct, discriminating between right/wrong and honest/dishonest and not harming others; and (4) discretionary or philanthropic: keenly contributing to community welfare by investing in education and charity or by helping society's most helpless members.

Although there are some notions about CSR, this study will focus on the CSR with the Islamic principle approach as a set of CSR practices to make a responsibility of all company activities holistically to stakeholders: humans, nature, and the God.

There are several theories that support the notion of CSR. First, the stakeholder theory posits that the behavior of an organization can be understood and predicted based on: (1) the nature of its diverse stakeholders; (2) the norms defining right or wrong adopted by these stakeholders; and (3) stakeholders' relative influence on organizational decisions. It means that the corporates pay attention to the needs and rights of all the stakeholders of a business as a useful way of developing socially responsible behavior by managers (Maignan \& Ferrell, 2004). Second, social contract theory, according to which business must act in a responsible manner, not only because it is in its commercial interest to do so, but also because it is a part of how society implicitly expects business to operate (Moir, 2001). Dusuki (2008) added two other theories as follows: (1) instrumental theory: in an attempt to further legitimize the role of corporations in society, an instrumental theory has developed CSR as a strategic tool to achieve economic objectives; and (2) legitimacy theory, which states that CSR is a response to the environmental pressures involving social, political, and economic forces. According to the theory, organizations look for a balance between their actions and how they are perceived by outsiders and what is thought by society to be appropriate.

Although CSR has underpinned with several theories above, CSR practices in IFIs have another rule which has to be fulfilled, that is, the Sharia law. Islam assumes a relatively holistic approach to CSR. This approach suggests an integrated spiritual vision of Sharia law, which is based on the Qur'an and Sunnah, to provide an alternative philosophical framework for people's relations with nature and other people. Indeed, the moral and ethical principles derived from divine revelations are enduring, eternal, and absolute (Ahmad, 2002). It can be inferred that this principle can be implemented as responsibility of corporations to society and the environment around them. CSR focuses on compliance to the sharia law to feature consistent with the unity, equilibrium, free will, and responsibility, and to organize these activities funded from Zakat and Qardh fund as shown in Table 2.

Abdullah and Suhaib (2011) said that Zakat is obligatory (Fard) on all Muslim men and women who are Sahib-e-Nisab and possess a specified limit of wealth, to pay each year a prescribed portion from capital or savings like farm produce, cattle, business activities, paper currency, and precious metals such as gold and 
silver. In PSAK 109, it was stated that Zakat is an Islamic obligation which must be submitted by muzakki to mustahik through amyl board or directly. Zakat is redeemable after eligible Nisab and haul, calculated at 2.5\% of the total object zakat and given to the mustahik. Meanwhile in PSAK 101, it was stated that Qardh (charity fund) is a voluntary donation such as infaq, charity, virtue productive refunds, fines and non-halal income. Based on PSAK 101, Qardh can be used to fund productive virtues, donations and has other use in the public interest. Febianto and Ashany (2012) said that Qardh is a kind of gratuitous loan given to the needy people for a fixed period without requiring the payment of interest or profit.

To fulfill the demands of various stakeholders with the goal of measuring CSR and in line with several researchers, the measurement of CSR can be based on the following: theme, evidence, news type, and number of sentences (Aras, Aybars, \& Kutlu, 2010; Lyon, 2007; Cochran \& Wood, 1984), disclosure index (Jitaree, Lodh, \& Bhati, 2014; Tsoutsoura, 2004), and employee, customer, community, environment, supplier and shareholder (Boaventura, Santos da Silva, \& Bandeira-de-Mello, 2012; Fischer \& Sawczyn, 2013).

Table 2

Scenario of Islamic CSR Practices

\begin{tabular}{|l|l|}
\hline Mode of CSR activities & CSR beneficiaries \\
\hline 1. Providing aids/equipments/booklets, etc. & 1. Educational activities \\
\hline 2. Financial assistance (Non-Zakat funds) & 2. Training and skill development \\
\hline 3. Construction work & 3. For differently disabled \\
\hline 4. Qardh al Hasana & 4. To needy, downtrodden \\
\hline 5. Financial assistance (Zakat funds) & 5. For marriage \\
\hline 6. Cooperation with other institutions & 6. For medical treatment \\
\hline 7. Organizing programmes, projects & 7. For diversified activities \\
\hline CSR collaborative agencies & 8. For medical equipments \\
\hline 1. With non-governmental organizations (NGOs) & 9. For prisoners \\
\hline 2. With government agencies & 10. For fishermen \\
\hline 3. With charity organizations & 11. For people affected by natural calamity \\
\hline 4. With other organizations & 12. For Zakat fund campaign \\
\hline & 13. For traffic awareness \\
\hline & 14. For religious activities \\
\hline & 15. For retiring employees \\
\hline & 16. For heritage club \\
\hline & 17. For women \\
\hline & 18. Employment to nationals \\
\hline & 19. For sports \\
\hline & 20. For environmental education \\
\hline
\end{tabular}

Note. Source: Chintaman (2014), modified.

All those measurements can also be used in IFIs as a commercial organization included IFIs in Indonesia. Moreover, during the last five years, the IFIs in Indonesia are required to disclose CSR in their annual reports as a complement report of their financial statements. It was a motivation of this research to explore deeply the role of CSR practices in the IFIs in Indonesia. Based on the previous research and the availability of the CSR report by IFIs, this study uses some of the measurements to count the scores of CSR disclosure from the annual report. They are distribution of Zakat and value of Qardh disclosure as uniqueness of IFIs report. 


\section{Corporate Financial Performance: Concept and Measurement}

About the definition of corporate financial performance, the researchers have various opinions. Fischer and Sawczyn (2013) suggested that corporate financial performance is defined as financial viability, or the extent to which a company achieves its economic goals. Lyon (2007) said that profitability is the most important aspect affecting a firm's growth and survival. It seems unlikely that a company could spend shareholders' funds without providing some kind of return. Cochran and Wood (1984) revealed that the basic idea underlying the financial performance is that the investor return is the return which should be measured from the perspective of the shareholders, such as price per share or share price appreciation, reflecting the notion that shareholders constitute a primary stakeholder group whose satisfaction determines the company's fate. Alternatively, accounting-based indicators, such as profit of the company, the firm's return on assets (ROA), return on equity (ROE), or earnings per share (EPS), capture a firm's internal efficiency in some way. On the other hand, Orlitzky, Schmidt, and Rynes (2003) stated that financial performance has been basically measured in three forms: market, accounting, and survey measurements.

One of the most complete measurement forms to measure the financial performance was expressed by Boaventura et al. (2012). They said that the variables most used to measure financial performance include the following: profit (operational and net), cash flow, EPS, ROA, ROE, sales growth, return on sales (ROS), contribution margin, Tobin's Q, market share, risk of the firm, and return on capital employed (ROCE).

Some elements of the financial statements of the IFIs have similarities with conventional institutions; therefore, financial performance measurement tools which are mentioned before can also be used to measure the financial performance of IFIs. Although, there are some addition elements as the compliance to the Islamic principles such as zakat report, charity funds report, and other reports. Therefore, based on some forms of financial measurement, this study focused on profit per year which is achieved of each company.

\section{Gender in IFIs as a Control Variable}

As we know that the role of gender in decision-making of organization has been issued in the research field. It is found that gender moderates the effect of other practices and personal characteristics on financial performance. In addition, females with a stronger motivation to establish a public practice to balance work and family experienced more positive financial outcomes (Collins-Dodd, Gordon, \& Smart, 2004). While for males, it is not always the case in the company as expressed by Inmyxai and Takahashi (2010) who stated that female entrepreneurs relatively underperform compared to male entrepreneurs.

Related to the CSR, females usually have a high sensitivity and concern over the implementation of CSR. This is because females are often soft-hearted and sensitive compared to males, as proposed by Kahreh, Babania, Tive, and Mirmehdi (2014). According to their study, the sensitivity of females is higher than males concerning the CSR dimensions of ethical responsibilities, discretionary responsibilities, legal responsibilities, and economic responsibilities. The $t$-test result of their study has also shown that all factors mentioned before significantly refer to the role of females compared with males. Despite the relative superiority of women orientation to the CSR, in accordance with the sig. amount, there is no significant and meaningful difference between males and females' orientation to the CSR in the organization. Finally, they found that females in dimensions of CSR have a little more attention compared with males. 
Leadership in organization was also often characterized by the emergence of female as a leader. There are some facts that few organizations are led by female, including some of the objects in this research, such as: BCA Sharia, Bank Panin Sharia, and Victoria Sharia Bank. Even the leadership in these cases can last for more than five years. Certainly, it is a phenomenon in this research, moreover, in the IFIs. As mentioned before that, females usually are often soft-hearted and sensitive compared to males, they are more sensitive to donate more funds. In line with Soares, Marquis, and Lee (2011), it is revealed that companies with more women board directors donated significantly more funds. With each additional woman, annual philanthropic giving increased more significantly by the Fortune 500 companies from 1997 to 2007.

\section{IAS for IFIs}

There is no denying that IFIs are closely related with adherence to the values of Islam. Therefore, one indicator that distinguished between IFIs and conventional institutions is the use of different standards. IFIs are expected to fulfill the financial statement as required by IAS.

Based on the narrative CSR and financial performance at the prior section that all of organizations including IFIs have to disclose their CSR to public with a standard to meet the goal of financial performance, at the same time, for IFIs, it must be suitable for the Islamic values. To produce CSR, IAS has to be present to regulate Islamic CSR reporting. As we know that IAS also refers to an Islamic sense and derived from the principle of the Qur'an. Napier (2009) revealed that Islamic accounting could be understood in a religion sense. What concepts of accountability are stated or implied in the authoritative sources of Islamic doctrine, the Qur'an (believed by Muslims to be the word of God revealed to the Prophet Muhammad SAW)? Meanwhile, Walsh (2007) stated that Islamic accounting (financing) is based on a system of ethics derived from the principles of the Qur'an. These ethical principles are applied to the financial industry through Sharia law.

Nowadays, there is an institution focus on the IAS. This institution has authority to product IAS. Sarea and Hanefah (2013) revealed that nowadays there is the Accounting and Auditing Organization for Islamic Financial Institutions (AAOIFI) which has an authority to product IAS. Then, IFIs have to adopt or comply with the AAOIFI accounting standards and IFRS has become the focus among IFIs. The AAOIFI provides guideline that may reflect the unique characteristics of IFIs and become a useful tool to meet the various needs of IFIs. AAOIFI has issued the characteristics of general standards and Islamic values disclosure in financial statement as Islamic bank must comply with Sharia regulation (Harahap, 2003). The objectives of the AAOIFI to establish IAS is to prepare and develop accounting, auditing, governance, ethical, and Sharia standards relating to the activities of IFIs. Based on the stakeholder theory, it discussed the importance of the AAOIFI's accounting standards for IFIs globally. Even, one of the major challenges facing IFIs lies in the preparation of financial statements under different accounting standards and which may result in problems of comparability, reliability, and compliance level's measurement, including how to produce the Islamic CSR. For Indonesia has Sharia PSAK as follows: PSAK 59 and 101-110.

IAS as a standard is different from other standards in the world. The core of this standard to arrange the company to make a report is fully in accordance with the principles of Islam. Firstly, it can be understood in a religious sense when the accounting rules are influenced by the religious dogma. Secondly, the label Islamic accounting can be applied to those countries where Islam had been the dominant religion at a certain moment in time. Given this last remark, we must mention that the influence of this religion on the national accounting rules may differ considerably from one country to another (Maria Dima, Dima, Megan, \& Paiusan, 2014). 
For example, the Islamic societies generally discourage the use of interest in business transactions. Usury is disallowed (Mirza \& Baydoun, 1999). Therefore, there exists a need for developing accounting and reporting standards that are relevant to Muslim firms. Accounting standards for firms in Islamic societies need to be broad and flexible. Too specific and complex rules are likely to impose costs on the firms and on the community. The accounting and reporting policy choices are likely to reflect the firms' contracting environments. Given the nature of the contracts, managers need to be encouraged to provide detailed information about the firms' performance in both financial and social domains.

Baydoun and Willett (2000) revealed a theory about the form and the content of the financial information that should be contained in Islamic financial statements. The theory suggests that the presence of the Islamic religion as a cultural variable affects the way certain accounting measures are interpreted and the manner in which accounting information should be disclosed. Two important criteria for disclosure in Islamic accounting are identified: a form of social accountability and a rule of full disclosure.

This leads to a modification of the form of the conventional Western set of financial statements, which are referred to in the paper as Islamic corporate reports (ICRs). The specific recommendations are that ICRs should contain a value-added statement as the focus of performance of the accounting entity and a current value balance sheet in addition to the historic cost balance sheet. It is argued that ICRs, extended in this way, would better serve the needs of users wishing to act in accordance with the Islamic code (Baydoun \& Willett, 2000).

IAS as a reference to conduct any transaction in the company must be consistent with the Islamic principle. According to Chintaman (2014), the fundamental principles of Islamic finance that IFIs transactions must comply with are as follows:

(1) Prohibition of interest or usury: The first and most important concept is that both the charging and the receiving of interest are strictly forbidden. This is commonly known as Riba or usury. Money, on its own, may not generate profits. When Riba infects an entire economy, it jeopardizes the well-being of everyone living in that society. When investors are more concerned with rates of interest and guaranteed returns than they are with the uses to which money is put, the results can only be negative;

(2) Ethical standards: The second guiding principle concerns the ethical standards. When Muslims invest their money in something, it is their religious duty to ensure that what they invest in is good and wholesome. It is for this reason that Islamic investing includes serious consideration of the business to be invested in, its policies, the products it produces, the services it provides, and the impact that these have on society and the environment. In other words, Muslims must take a close look at the business they are about to become involved in. No investments that are not in the public interest. Transactions involving certain products are prohibited; these include: pork, alcohol, armaments, gambling, and conventional finance;

(3) Moral and social values: The third guiding principle concerns moral and social values. The Qur'an calls on all its adherents to care for and support the poor and destitute. IFIs are expected to provide special services to those in need. This is not confined to mere charitable donations but has also been institutionalized in the industry in the form of profit-free loans or Al Qard Al Hasanas;

(4) Liability and business risk: The final principle concerns the overarching concept of fairness, the idea that all parties concerned should both share in the risk and profit of any endeavor. To be entitled to a return, a provider of finance must either accept business risk or provide some service such as supplying an asset, otherwise the financier is, from a Sharia point of view, not only an economic parasite but also a sinner. 
This principle is derived from a saying of the Prophet Mohammed (May Peace be upon Him), "Profit comes with liability". What this means is that one becomes entitled to profit only when one bears the liability, or risk of loss. By linking profit with the possibility of loss, Islamic law distinguishes lawful profit from all other forms of gain.

\section{Research Method}

\section{The Samples}

This paper used the annual report of nine Islamic banks as one of the three types of IFIs in Indonesia. The names of the nine Islamic banks are: Muamalat Bank, Bank Sharia Mandiri, BRI Sharia, BNI Sharia, Bank Panin Sharia, Mega Sharia Bank, Victoria Sharia Bank, BCA Sharia Bank, and Bank BJB Sharia. Besides, two sharia banks such as Bank Sharia Bukopin and Maybank Sharia are excluded in the analysis, because they have not completed the annual report as IAS appointed.

Data were collected for five years from Islamic bank annual report from 2010 to 2014. From the annual report, data were classified and calculated from a company's CSR practices with Zakat and Qardh report. The instruments of these reports are distribution of Zakat (Dist_Zakat) and value of Qardh (VQardh) as sources of funding to do CSR practices related to companies stakeholder satisfaction, and for financial performance using profit per year for each Islamic bank. Furthermore, data were calculated using SPSS Version 22 as a statistical analysis to measure the relationship between company's CSR practices and financial performance.

\section{Research Model}

To measure the relationship between CSR practices and financial performance in IFIs, we used Islamic banks data having gender as a control variable. The research model we used is shown in Figure 1 as follows.

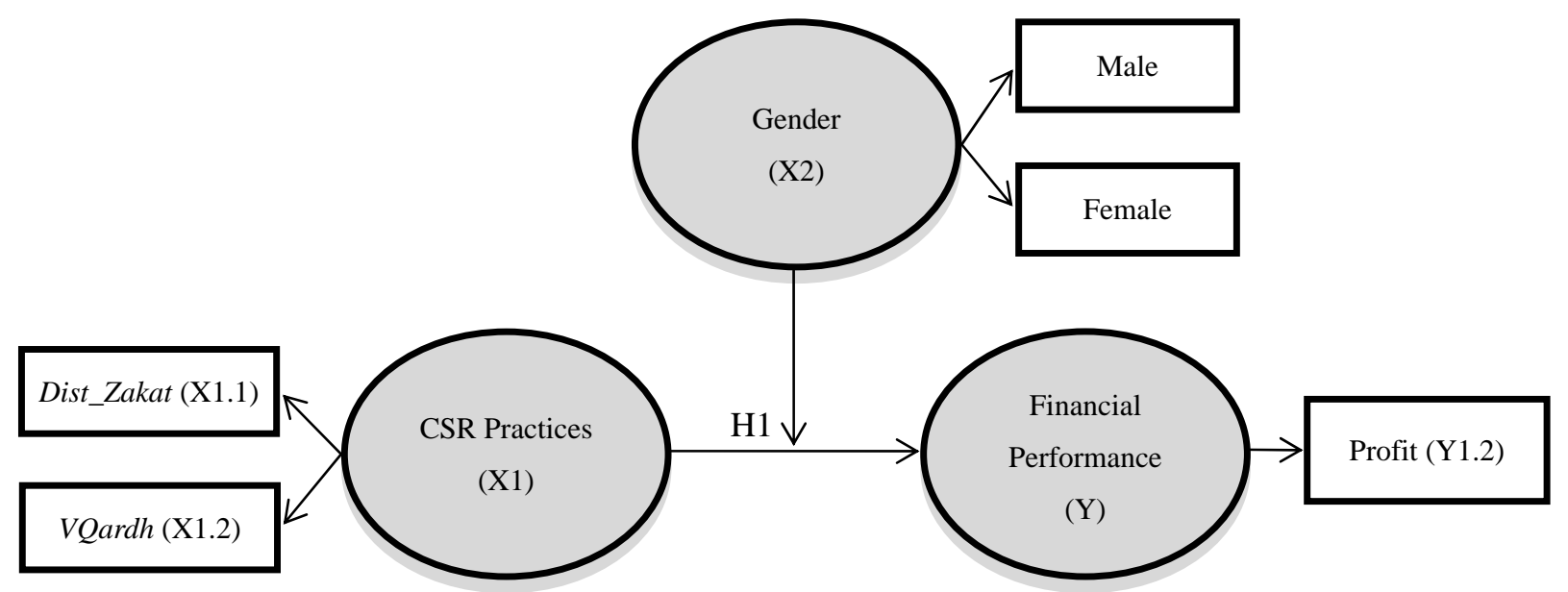

Figure 1. Research model. Note. Dist_Zakat = A number of Zakat has been distributed in x-year; VQardh = Qardh collected and distributed in x-year; Gender = Male or female as a control variable.

\section{Operational Definitions}

To understand the relationship between CSR practices and financial performance using IAS as a control variable, the definition of variables is as follows: 
CSR practices are an organization's commitment to conducting its business in an economically, socially, and environmentally sustainable manner whilst balancing the interests of a diverse range of stakeholders, and it was measured with evidence of monetary quantification (Aras et al., 2010; Cochran \& Wood, 1984; Jitaree et al., 2014).

Financial performance is financial viability, or the extent to which a company achieves its economic goals, and it was measured with net profit, ROA, and ROE (Aras et al., 2010; Boaventura et al., 2012; Cochran \& Wood, 1984; Jitaree et al., 2014; Lyon, 2007; Fischer \& Sawczyn, 2013; Tsoutsoura, 2004).

Gender is the concept of a set of characteristics associated with a person's sex and directed at the social role or identity in society (Wikipedia, 2015; Collins-Dodd et al., 2004; Inmyxai \& Takahashi, 2010; Soares et al., 2011; Kahreh et al., 2014).

\section{Development of Hypotheses}

To be more formally, the paper tests the following series of broad hypotheses of the relationship between CSR practices and financial performance. One of the most important theories that underpin the definition and development of CSR is the stakeholder theory. Stakeholder theory requires the roles of companies to the surrounding communities, such as: environmental improvement, increasing the quality of human resources, involving in any jobs or reducing unemployment and any other activities. According to Maignan and Ferrell (2004), paying attention to the needs and rights of all the stakeholders in a business is a useful way of developing socially responsible behavior by managers. Stakeholder theory posits that the behavior of an organization can be understood and predicted based on: (1) the nature of its diverse stakeholders; (2) the norms defining right or wrong adopted by these stakeholders; and (3) stakeholders' relative influence on organizational decisions. Dusuki (2008) said that stakeholder theory is also an attempt to broaden the perception that there is only one dominant interest, namely, the shareholders in public companies.

Based on the theory, some studies examine and investigate the relationship between CSR and financial performance in any contexts. However, some of these studies have indicated a positive relationship between CSR and financial performance, whereas others have not. One of this studies that investigated this relationship from the annual report listed on the stock exchange of Thailand during the period of 2009-2011 is that of Jitaree et al. (2014). They concluded that there was a strong positive relationship between CSR and financial performance in Thai listed firms. Tsoutsoura (2004) examined the relationship between CSR and financial performance in more than half of the Fortune 1000 companies which issued CSR reports in USA. It indicated that CSR is positively related to better financial performance and this relationship is statistically significant, supporting, therefore, the view that socially responsible corporate performance can be associated with a series of bottom-line benefits.

Ekatah, Samy, Bampton, and Halabi (2011) concluded that the findings indicate that CSR is positively related to better financial performance (profitability) and this relationship is statistically significant. Lyon (2007) said that profitability is the most important aspect affecting a firm's growth and survival and it can be seen from the positive relationship between CSR and profitability. Some of the researchers had the same conclusion such as Boaventura et al. (2012), Cochran and Wood (1984), Fischer and Sawczyn (2013), and Bayrakdaroglu, Ersoy, and Citak (2012).

Whereas, Aras et al. (2010) examined the annual reports of 40 companies which were selected after removing the companies in the financial sector and two companies in the automobile sector, and they found no 
link between CSR and financial performance, they only found a relationship between firm size and CSR. They also said that CSR is still a very broad and active research topic, not only in emerging market countries, and the strength and usefulness of many results are still hotly debated. Thus, it is no easy task to consistently evaluate their significance. In other cases, Brine, Brown, and Hackett (2006) investigated the Australian companies to examine the relationship between CSR and financial performance and their study found no significant relationship. They faced the research constraint in conducting this analysis which was the lack of a reliable measure of CSR. It is not clear how to assess the extent to which corporate decision-making encompasses the social and environmental consequences of a course of actions.

In spite of many different conclusions on the relationship between CSR practices and financial performance as we found from the studies mentioned above, this research will focus on IFIs as a new field study to enrich the study about the relationship between CSR and financial performance with gender as a control variable. As we know that gender plays a more important role in making a decision in corporations.

So, this research will examine and investigate the relationship between CSR and financial performance, especially the case in IFIs in Indonesia. For this purpose, we design the following hypotheses:

H0: There is not a significant relationship between CSR practices and financial performance with gender of the board of directors as a control variable.

H1: There is a significant relationship between CSR practices and financial performance with gender of the board of directors as a control variable.

\section{Findings}

To analyze the gathered data and test the research hypotheses, in this section, both descriptive and analytical statistics have been implemented. Participants of this research include nine Islamic banks with each annual report for five years from 2010 to 2014. Table 3 below best describes the population's characteristics and presents a descriptive statistics analysis.

Table 3

The Research Population Characteristics and Descriptive Analysis

\begin{tabular}{llcccc}
\hline Frequencies & & Frequency & Percent (\%) & $\begin{array}{c}\text { Valid } \\
\text { percent (\%) }\end{array}$ & $\begin{array}{c}\text { Cumulative } \\
\text { percent (\%) }\end{array}$ \\
\hline & BCA Sharia & 5 & 11.1 & 11.1 & 11.1 \\
& BJB Sharia & 5 & 11.1 & 11.1 & 22.2 \\
& BNI Sharia & 5 & 11.1 & 11.1 & 33.3 \\
& BRI Sharia & 5 & 11.1 & 11.1 & 44.4 \\
Valid & Mega Sharia Bank & 5 & 11.1 & 11.1 & 55.5 \\
& Muamalat Bank & 5 & 11.1 & 11.1 & 66.6 \\
& Bank Panin Sharia & 5 & 11.1 & 11.1 & 77.7 \\
& Bank Sharia Mandiri & 5 & 11.1 & 11.1 & 88.8 \\
& Victoria Sharia Bank & 5 & 11.1 & 11.1 & 99.9 \\
& Total & 45 & 99.9 & 99.9 & Profit \\
\hline Mean & & Descriptive analysis & & $37,363.11$ \\
Std. error of mean & VQardh & CSR practices & Gender & $34,276.63$ \\
Std. dev. & Dist_Zakat & $2,043.84$ & $3,816.28$ & 0.67 & $339,934.61$ \\
\hline
\end{tabular}

Note. Source: Data modified (2015). 
In order to test the validity of the research hypotheses, we used an ANOVA model as can be seen in Table 4. As demonstrated in Table 4, we can know that sig. is $0.000(<0.05)$, which means that H0 predicting that there is no significant relationship between CSR practices and financial performance has been rejected and $\mathrm{H} 1$ stating that CSR practices have a positive impact on financial performance in the IFIs has been accepted.

Table 4

Result of ANOVA Analysis for CSR Practices to Profit (Dependent Variable = Profit)

\begin{tabular}{lllrlll}
\hline Model & & Sum of squares & df & Mean squares & $F$ & Sig. \\
\hline \multirow{2}{*}{1} & Regression & $1.262 \mathrm{E}+12$ & 1 & $1.262 \mathrm{E}+12$ & 51.032 & $0.000^{\mathrm{a}}$ \\
& Residual & $1.064 \mathrm{E}+12$ & 43 & $2.474 \mathrm{E}+12$ & & \\
& Total & $2.326 \mathrm{E}+12$ & 44 & & & \\
\hline
\end{tabular}

Note. ${ }^{\text {a. }}$ Predictors: (Constant), CSR practices.

Meanwhile, we measure the strength and influence of CSR practices on corporate financial performance as shown in Table 5. Based on Table 5, it is shown that the value of $R$ is 0.737 , meaning that there is a correlation between CSR practices and financial performance of IFIs in Indonesia with a very strong correlation and positive trend.

Table 5

Result of Model Summary Analysis (Dependent Variable $=$ Profit)

\begin{tabular}{lllll}
\hline Model & $R$ & $R$ square & Adjusted $R$ square & Std. error \\
\hline 1 & $0.737^{\mathrm{a}}$ & 0.543 & 0.532 & $157,286.9952$ \\
\hline Note. ${ }^{\text {a }}$. Predictors: (Constant), CSR practices. & & &
\end{tabular}

On the other hand, as seen from Table 5 , the value of $R$ square is 0.543 or $54.3 \%$. It means that CSR practices influenced financial performance Islamic banks in the amount of $54.3 \%$ and the balance of $45.7 \%$ is influenced by other factors.

Table 6

Result of T-test for CSR Practices to Profit (Dependent Variable = Profit)

\begin{tabular}{llccccc}
\hline \multirow{2}{*}{ Model } & \multicolumn{2}{c}{ Unstandardized coefficient } & $\begin{array}{l}\text { Standardized } \\
\text { coefficient }\end{array}$ & $t$ & \multirow{2}{*}{ Sig. } \\
\hline \multirow{2}{*}{1} & (Constant) & $57,217.317$ & $27,318.257$ & & 2.094 & 0.042 \\
& CSR practices & 26.242 & 3.673 & 0.737 & 7.144 & 0.000 \\
\hline
\end{tabular}

Furthermore, based on the result of data processing for $t$-test using SPSS Version 22 as shown in Table 6, it can be clearly seen (also in accordance with the significant and calculated means) that CSR practices are positively related to the main research variable, namely, financial performance.

Besides, the result of partial correlation analysis examining the correlation between CSR practices and financial performance with gender as a control variable is shown in Table 7. Based on Table 7, it is explained that the correlation between CSR practices and financial performance has changed from 0.737 (before using gender as a control variable) to 0.679 (after using gender as a control variable). This change indicates a decrease in the value of the correlation, though the change is still strong which is above $50 \%$. It shows that even gender has been used as a control variable, the relationship between CSR practices and financial performance is still strong. 
Table 7

Result of Partial Correlation Using Gender as a Control Variable

\begin{tabular}{|c|c|c|c|c|c|}
\hline \multicolumn{3}{|c|}{ Control variable } & \multirow{2}{*}{$\begin{array}{c}\text { Profit } \\
1.000\end{array}$} & \multirow{2}{*}{$\begin{array}{c}\text { CSR practices } \\
0.737\end{array}$} & \multirow{2}{*}{$\begin{array}{r}\text { Gender } \\
0.440\end{array}$} \\
\hline \multirow{9}{*}{-None- ${ }^{\mathrm{a}}$} & \multirow{3}{*}{ Profit } & Correlation & & & \\
\hline & & \multicolumn{2}{|l|}{ Significance (2-tailed) } & 0.000 & 0.002 \\
\hline & & df & 0 & 43 & 43 \\
\hline & \multirow{3}{*}{ CSR practices } & Correlation & 0.737 & 1.000 & 0.409 \\
\hline & & Significance (2-tailed) & 0.000 & & 0.005 \\
\hline & & df & 43 & 0 & 43 \\
\hline & \multirow{3}{*}{ Gender } & Correlation & 0.440 & 0.409 & 1.000 \\
\hline & & Significance (2-tailed) & 0.002 & 0.005 & \\
\hline & & df & 43 & 43 & 0 \\
\hline \multirow{6}{*}{ Gender } & \multirow{3}{*}{ Profit } & Correlation & 1.000 & 0.679 & \\
\hline & & Significance (2-tailed) & & 0.000 & \\
\hline & & df & 0 & 42 & \\
\hline & \multirow{3}{*}{ CSR practices } & Correlation & 0.679 & 1.000 & \\
\hline & & Significance (2-tailed) & 0.000 & & \\
\hline & & df & 42 & 0 & \\
\hline
\end{tabular}

Note. ${ }^{\mathrm{a}}$. Cells contain zero-order (Pearson) correlations.

Moreover, the correlation coefficient also shows a positive value, which means that the relationship between CSR practices and financial performance is positive and proportional. Furthermore, we can conclude that corporations which are more obedient in distributing Zakat and Qardh will generate better financial performance.

\section{Conclusion and Future Research Direction}

The presences of IFIs in society where the majority are Muslims, such as Indonesia, would provide enormous benefits: the availability of IFIs based on Sharia on one hand; and the implementation of the value of Islam by Muslims in the life of community on the other hand, including the implementation of CSR.

CSR is a form of responsibility of all company activities holistically to stakeholders: humans, nature, and the God. With this principle, the community could feel the usefulness of CSR practices from IFIs. CSR practices can help to systematically address stakeholder demands and secure stakeholder support and finally, it will increase the quality of financial performance (Maignan \& Ferrell, 2004; Dusuki, 2008).

Based on the result of analysis above, it can be concluded that the relationship between CSR practices and financial performance is strong $(R=0.737 ; R$ square $=0.543)$. It means that there is a relationship between CSR practices and financial performance of IFIs in Indonesia. The conclusion of this research reinforced the result of previous studies stating a positive relationship between CSR and corporate financial performance such as Cochran and Wood (1984), Tsoutsoura (2004), Lyon (2007), Boaventura et al. (2012), Fischer and Sawczyn (2013), and Jitaree et al. (2014).

Besides, the result of partial correlation analysis examining the correlation between CSR practices and financial performance with gender as a control variable is still strong which is above $50 \%$. It showed that although other variable which also affected financial performance such as gender is controlled, actually, the correlation between CSR practices and financial performance is still strong. Therefore, it can be concluded that the correlation between CSR practices and financial performance is strong. 
Although we found a significant relationship between CSR practices and financial performance especially for IFIs in Indonesia, which is consistent with the majority of previous studies, this study still has a limitation, as we know that this research only focuses on funding of Zakat and Qardh for CSR practices and profit for financial performance. We hope that future research can advance the variable of CSR practices to each item's activities, for example: the real CSR practice; which activities of CSR practices influence the financial performance the most? On the other hand, for future research, other measurements of financial performance, such as EPS, can also be used.

\section{References}

Abdullah, M., \& Suhaib, A. Q. (2011). The impact of Zakat on social life of Muslim society. Pakistan Journal of Islamic Research, 8, 85-91.

Ahmad, K. (2002). Islamic ethics in a changing environment for managers. In K. A. Mohd Israil, \& A. M. Sadeq (Eds.), Ethics in business and management: Islamic and mainstream approaches. London: Asean Academic Press.

Aras, G., Aybars, A., \& Kutlu, O. (2010). Managing corporate performance: Investigating the relationship between corporate social responsibility and financial performance in emerging markets. International Journal of Productivity and Performance Management, 59(3), 229-254.

Baydoun, N., \& Willett, R. (2000). Islamic corporate reports. Abacus, 36(1), 71-90.

Bayrakdaroglu, A., Ersoy, E., \& Citak, L. (2012). Is there a relationship between corporate governance and value-based financial performance measures? A study of Turkey as an emerging market. Asia-Pacific Journal of Financial Studies, 41(2), $224-239$.

Boaventura, J. M. G., Santos da Silva, R., \& Bandeira-de-Mello, R. (2012). Corporate financial performance and corporate social performance: Methodological development and the theoretical contribution of empirical studies. Revista Contabilidade \& Finanças - USP, 23(60), 232-245.

Brine, M., Brown, R., \& Hackett, G. (2006). Corporate social responsibility and financial performance in the Australian context. Australian Treasury.

Carroll, A. B. (1979). A three-dimensional conceptual model of corporate performance. Academy of Management Review, 4(4), 497-505.

Chintaman, S. A. (2014). A comparative study of CSR practices of Islamic banks and conventional banks in GCC region. Journal of Islamic Banking and Finance, 2(1), 1-21.

Cochran, P. L., \& Wood, R. A. (1984). Corporate social responsibility and financial performance. Academy of Management Journal, 27(1), 42-56.

Collins-Dodd, C., Gordon, I. M., \& Smart, C. (2004). Further evidence on the role of gender in financial performance. Journal of Small Business Management, 42(4), 395-417.

Dusuki, A. W. (2008). What does Islam say about corporate social responsibility (CSR)? Review of Islamic Economics, 12(1), 5-28.

Ekatah, I., Samy, M., Bampton, R., \& Halabi, A. (2011). The relationship between corporate social responsibility and profitability: The case of Royal Dutch Shell Plc. Corporate Reputation Review, 14(4), 249-261.

Febianto, I., \& Ashany, A. M. (2012). The impact of Qardhul Hasan financing using Zakah funds on economic empowerment (Case study of Dompet Dhuafa, West Java, Indonesia). Asian Business Review, 1(1), 15-20.

Fischer, T. M., \& Sawczyn, A. A. (2013). The relationship between corporate social performance and corporate financial performance and the role of innovation: Evidence from German listed firms. Journal of Management Control, 24(1), 27-52. doi: 10.1007/s00187-013-0171-5

Friedman, M. (1970, September 13). The social responsibility of business is to increase its profit. New York Times, pp. 122-126.

Garriga, E., \& Mele, D. (2004). Corporate social responsibility theories: Mapping the territory. Journal of Business Ethics, 53(1-2), 51-71.

Harahap, S. S. (2003). The disclosure of Islamic values - annual report. The analysis of Bank Muamalat Indonesia's annual report. Managerial Finance, 29(7), 70-89.

Inmyxai, S., \& Takahashi, Y. (2010). Performance contrast and its determinants between male and female headed firms in Lao MSMEs. International Journal of Business and Management, 5(4), 37-52. 
Jitaree, W., Lodh, S. C., \& Bhati, S. S. (2014). The relationship between corporate social responsibility disclosure and financial performance: Evidence from Thailand. Paper presented at the 26th Asian-Pacific Conference on International Accounting Issues (p. 17), California State University, United States.

Kahreh, M. S., Babania, A., Tive, M., \& Mirmehdi, S. M. (2014). An examination to effects of gender differences on the corporate social responsibility (CSR). Elsevier, Procedia - Social and Behavioral Sciences, 109, 664-668.

Lyon, D. (2007). Financial performance: The motivation behind corporate social responsibility reporting (Dissertation, University of Otago, Dunedin, New Zealand).

Maignan, L., \& Ferrell, O. C. (2004). Corporate social responsibility and marketing: An integrative framework. Journal of the Academy of Marketing Science, 32(1), 3-19.

Maria Dima, S., Dima, B., Megan, O., \& Paiusan, L. (2014). A discussion over IFRS' adoption in Islamic countries. Journal of Accounting and Management Information Systems, 13(1), 35-49.

Mirza, M., \& Baydoun, N. (1999). Do Islamic societies need their own accounting and reporting standards? Journal of the Academy of Business Administration, 4(2), 39-45.

Moir, L. (2001). What do we mean by corporate social responsibility? Corporate Governance: International Journal of Business in Society, 1(2), 16-22.

Napier, C. (2009). Defining Islamic accounting: Current issues, pass roots. Accounting History, 14(1/2), 121-144.

Orlitzky, M., Schmidt, F. L., \& Rynes, S. L. (2003). Corporate social and financial performance: A meta-analysis. Organization Studies, 24(3), 403-441.

Otoritas Jasa Keuangan [OJK]. (2014). Pebankan Syariah di Wilayah Sulawesi Selatan dan Barat (Sulselbar). Kantor OJK Regional 6 Sulampua.

Rahman, H. (2009). Tafsir Qur'an per Kata. Jakarta: Magfirah Pustaka.

Sarea, A. M., \& Hanefah, M. M. (2013). The need of accounting standards for Islamic financial institutions. International Management Review, 9(2), 50-59.

Siwar, C., \& Hossain, T. (2009). An analysis of Islamic CSR concept and the opinions of Malaysian managers. Management of Environmental Quality: An International Journal, 20(3), 290-298.

Soares, R., Marquis, C., \& Lee, M. (2011). Gender and corporate social responsibility: It's a matter of sustainability. Retrieved from http://www.catalyst.org/knowledge/gender-and-corporate-social-responsibility-its-matter-sustainability

Tsoutsoura, M. (2004). Corporate social responsibility and financial performance. Haas School of Business, University of California at Berkeley, USA.

Walsh, C. (2007). Ethics: Inherent in Islamic finance through Shari’a law; Resisted in American business despite Sarbanes-Oxley. Fordham Journal of Corporate \& Financial Law, 12(4), 753-777.

Wikipedia. (2015). Gender (Social). Retrieved from https://id.wikipedia.org/wiki/Gender_\%28sosial\%29

Zakaria, A. A., \& Gao, S. S. (2011). Narrative disclosure of corporate social responsibility in Islamic financial institutions. Managerial Auditing Journal, 27(2), 199-222. 